\title{
PENGARUH SUHU TERHADAP PERMEABILITAS GAS PADA PLASTIK FILM UNTUK PENGEMASAN SECARA ATMOSFIR TERMODIFIKASI
}

\section{THE EFFECT OF TEMPERATURE ON THE GAS PERMEABILITY OF POLYMERIC FILM FOR MODIFIED ATMOSPHERE PACKAGING}

\author{
Rokhani Hasbullah $^{1}$, Agus Ghautsun Niam ${ }^{1}$, Lilik Pujantoro', Sutrisno Mardjan ${ }^{1}$ \\ ${ }^{1}$ Departemen Teknik Mesin dan Biosistem, Institut Pertanian Bogor, Bogor, Indonesia. \\ ${ }^{\square}$ Komunikasi Penulis, e-mail:rokhani@apps.ipb.ac.id \\ DOI:http://dx.doi.org/10.23960/jtep-lv7i3.133-141
}

Naskah ini diterima pada 17 September 2018; revisi pada 27 Desember 2018;

disetujui untuk dipublikasikan pada 27 Desember 2018

\begin{abstract}
Modified Atmosphere Packaging (MAP) in cold storage is a particular method to maintain the quality and freshness of minimally processed produce. The objectives of this research is to study the effect of temperature on the gas permeability of polymeric film for modified atmosphere packaging of minimally processed produce. Polymeric films of polyethylene stretch (10 $\mu \mathrm{m}$ thickness) and polypropylene (10 $\mu \mathrm{m}$ thickness) were used in this experiment. The gas permeability of the plastic films to $\mathrm{O}_{2}$ and $\mathrm{CO}_{2}$ were analyzed using gas chromatograph $\mathrm{HP}$ 5890 at temperature of $5,10,15,20$, and $25^{\circ} \mathrm{C}$ based on a steady state concentration increase method. The results showed that the gas permeability increased with increasing temperature storage. An Arrhenius equation model expressed the temperature effect on gas permeability fitted very well with the coefficient of determination $\left(R^{2}\right)$ values ranging between 0.9586 and 0.9943 .
\end{abstract}

Keywords: gas permeability, polymeric film, modified atmosphere packaging, minimally process

\begin{abstract}
ABSTRAK
Pengemasan secara atmosfir termodifikasi (MAP) pada penyimpanan dingin merupakan cara yang tepat untuk menjaga kualitas dan kesegaran produk yang diolah secara minimal. Tujuan dari penelitian ini adalah untuk mengkaji pengaruh suhu terhadap permeabilitas gas pada plastik film untuk pengemasan secara atmosfir termodifikasi pada produk olahan minimal. Plastik film jenis polietilen stretch (ketebalan $10 \mathrm{~mm}$ ) dan polipropilen (ketebalan $10 \mathrm{~mm}$ ) digunakan dalam penelitian ini. Permeabilitas gas plastik film terhadap gas $\mathrm{O}_{2}$ dan $\mathrm{CO}_{2}$ dianalisis menggunakan kromatografi gas HP 5890 pada suhu 5, 10, 15, 20, dan $25^{\circ} \mathrm{C}$ berdasarkan metode konsentrasi meningkat kondisi stabil. Hasil penelitian menunjukkan bahwa permeabilitas gas meningkat dengan meningkatnya suhu penyimpanan. Model persamaan Arrhenius mampu menggambarkan pengaruh suhu terhadap permeabilitas gas sangat baik dengan nilai koefisien determinasi $\left(\mathrm{R}^{2}\right)$ berkisar antara 0.9586 dan 0.9943.
\end{abstract}

Kata kunci: permeabilitas gas, film polimer, modifikasi kemasan atmosfer, pengolahan minimal

\section{PENDAHULUAN}

\section{Pengemasan MAP}

Pengemasan secara atmosfir termodifikasi (modified atmosphere packaging, MAP) dan penyimpanan dingin merupakan salah satu solusi untuk memperpanjang masa simpan buah-buahan atau sayuran terolah minimal. Seiring dengan tuntutan konsumen yang menginginkan produk yang "ready to serve" dan "ready to eat" pemasaran produk segar terolah minimal memiliki prospek yang cerah. Di Thailand, pemasaran produk segar terolah minimal cukup berkembang pesat. Pengemasan MAP umumnya menggunakan film plastik yang memiliki permeabilitas tinggi sehingga terjadi efek modifikasi komposisi gas di dalam kemasan sehingga konsentrasi gas $\mathrm{O}_{2}$ lebih rendah dan gas $\mathrm{CO}_{2}$ lebih tinggi dari kondisi udara normal. Efek modifikasi atmosfir ini menyebabkan laju respirasi produk menurun sehingga dapat memperpanjang masa simpan produk. Film 
plastik sudah banyak diaplikasikan pada buahbuahan/sayuran dan terbukti efektif dalam mempertahankan mutu buah-buahan selama penyimpanan. Film plastik juga memberikan perlindungan terhadap kehilangan air pada buah-buahan atau sayuran sehingga dapat mempertahankan kesegaran produk yang dikemas (Smock 1979).

Pengemasan MAP adalah pengemasan produk dengan menggunakan bahan kemasan yang dapat menahan keluar masuknya gas (terutama $\mathrm{O}_{2}$ dan $\mathrm{CO}_{2}$ ) sehingga konsentrasi gas di dalam kemasan berubah dan menyebabkan laju respirasi produk menurun, mengurangi pertumbuhan mikrobia, mengurangi kerusakan oleh enzim serta memperpanjang umur simpan. Pengemasan MAP dianggap berhasil apabila mampu mengurangi laju pematangan sekaligus mencegah terjadinya pembusukan dan penyimpangan lain serta mampu mempertahankan kesegaran produk yang dikemasnya. Faktor-faktor yang mempengaruhi pengemasan MAP antara lain adalah faktor produk (varietas, tingkat kematangan, struktur permukaan, ukuran dimensi, berat produk, laju respirasi, dan lainlain), faktor kemasan (jenis film plastik, nilai permeabilitasnya, luas permukaan dan ketebalannya), dan faktor lingkungan (suhu dan kelembaban ruang penyimpanan). Model matematik pengemasan MAP dapat dirumuskan dengan Persamaan berikut (Manapperuma et al. 1989).

$$
\begin{aligned}
& \text { Oksigen : } \quad V \frac{d x 1}{d t}=\frac{p_{1} A}{b}\left(y_{1}-x_{1}\right)-W R_{1} \\
& \text { Karbondioksida: } V \frac{d x 2}{d t}=\frac{P_{2} A}{b}\left(y_{2}-x_{2}\right)+W R_{2}
\end{aligned}
$$

\section{Dimana:}

$$
\begin{aligned}
& \mathrm{W}=\text { berat produk dalam kemasan }(\mathrm{kg}) \\
& \mathrm{R}=\text { laju respirasi }(\mathrm{ml} / \mathrm{kg} . j \mathrm{jam}) \\
& \mathrm{A}=\text { luas permukaan plastik }\left(\mathrm{m}^{2}\right) \\
& \mathrm{y}=\text { konsentrasi gas udara lingkungan } \\
& \quad \text { (desimal) } \\
& \mathrm{x}=\text { konsentrasi gas dalam kemasan } \\
& \text { (desimal) } \\
& \mathrm{b}=\text { tebal film kemasan }(\mathrm{mm}) \\
& \mathrm{P}=\text { permeabilitas film kemasan (ml.mm/ } \\
& \quad \mathrm{m}^{2} \text {.jam.atm) } \\
& \mathrm{t}=
\end{aligned}
$$

Persamaan (1) dan (2) dapat diintegralkan menjadi sebuah persamaan untuk mendapatkan konsentrasi gas $\mathrm{O}_{2}$ dan $\mathrm{CO}_{2}$ optimum dalam kemasan yang digunakan dalam simulasi MAP, dengan persamaan yang mempunyai fungsi hubungan dari waktu, sebagai berikut (Fonseca 2000):

$$
\begin{aligned}
& x_{1}(t)=x_{1}{ }^{s}-\left(x_{1}{ }^{s}-0.21\right) \exp \left(-\frac{P A}{b} \frac{t}{V}\right) \\
& x_{2}(t)=x_{2}{ }^{s}+\left(0.0003-x_{2}{ }^{s}\right) \exp \left(-\frac{P A}{b} \frac{t}{V}\right)
\end{aligned}
$$

Dimana:

$$
\begin{aligned}
\mathrm{x}(\mathrm{t})= & \text { konsentrasi gas pada waktu tertentu } \\
& \text { (desimal) } \\
x^{s}= & \text { konsentrasi gas pada steady state } \\
& \text { (desimal) } \\
\mathrm{t}= & \text { waktu (jam) } \\
\mathrm{V}= & \text { volume bebas }(\mathrm{ml}) \\
\mathrm{P}= & \text { permeabilitas kemasan } \\
& \text { (mlmm.jam.atm } \left./ \mathrm{m}^{2}\right) \\
\mathrm{A}= & \text { luas permukaan kemasan }\left(\mathrm{m}^{2}\right) \\
\mathrm{b}= & \text { ketebalan kemasan }(\mathrm{mm})
\end{aligned}
$$

Subskrip 1 dan 2 masing-masing menyatakan oksigen dan karbondioksida.

Dalam pengemasan sistem MAP, tahapan perancangan adalah sebagai berikut:

(1)Menetapkan komposisi gas optimum dari produk yang akan dikemas, yaitu konsentrasi $\mathrm{O}_{2}\left(\mathrm{x}_{1}\right)$ dan $\mathrm{CO}_{2}\left(\mathrm{x}_{2}\right)$ yang nilainya berbeda-beda untuk setiap jenis komoditas.

(2)Menentukan laju respirasi produk pada komposisi gas optimum tersebut, meliputi laju konsumsi $\mathrm{O}_{2}\left(\mathrm{R}_{1}\right)$ dan laju poduksi $\mathrm{CO}_{2}$ $\left(\mathrm{R}_{2}\right)$.

(3)Memilih jenis plastik film kemasan yang sesuai nilai permeabilitasnya, baik permeabilitas terhadap $\mathrm{O}_{2}\left(\mathrm{P}_{1}\right)$ maupun terhadap $\mathrm{CO}_{2}\left(\mathrm{P}_{2}\right)$.

(4) Menetapkan ketebalan (b) dan luas permukaan $(A)$ dari plastik film kemasan serta berat produk yang akan dikemas $(W)$, sedemikian rupa sehingga memenuhi persamaan model matematika sistem pengemasan MAP pada kondisi kesetimbangan.

(5)Apabila data respirasi tidak tersedia maka dilakukan simulasi dengan mengubah-ubah nilai $W, b$ dan $A$ sehingga menghasilkan komposisi gas di dalam kemasan mendekati komposisi optimum yang direkomendasikan. 


\section{Permeabilitas Plastik Film}

Kemasan plastik saat ini mendominasi industri makanan di Indonesia, menggeser penggunaan kemasan logam dan gelas. Hal ini disebabkan karena kelebihan dari kemasan plastik yaitu ringan, fleksibel, multiguna, kuat, tidak bereaksi, tidak berkarat dan bersifat termoplastis (heat seal), dapat diberi warna dan harganya yang murah. Kelemahan dari plastik karena adanya zat monomer dan molekul kecil dari plastik yang mungkin bermigrasi ke dalam bahan pangan yang dikemas. Kader dan Moris (1977) mengemukakan bahwa pengemasan buah dalam film plastik yang permeabel merupakan sistem dinamik dan meliputi dua proses yang terjadi bersamaan yaitu proses pernapasan dan perembesan $\mathrm{O}_{2}$ dan $\mathrm{CO}_{2}$ ke luar dan ke dalam kemasan. Oksigen secara terus-menerus digunakan oleh buah untuk kegiatan pernapasannya menghasilkan $\mathrm{CO}_{2}, \mathrm{H}_{2} \mathrm{O}$ dan energi panas, akibatnya terjadi perbedaan konsentrasi $\mathrm{O}_{2}$ antara bagian dalam dan bagian luar kemasan sehingga $\mathrm{O}_{2}$ mulai merembes ke dalam kemasan. Konsentrasi $\mathrm{CO}_{2}$ dalam kemasan yang semakin meningkat dalam waktu yang bersamaan akan merembes ke luar kemasan.

Beberapa metode yang telah dikembangkan untuk pengukuran permeabilitas gas dapat dibedakan berdasarkan prinsip kerjanya menjadi: metode tekanan meningkat, volume meningkat dan konsentrasi meningkat. Prinsip tekanan meningkat dan volume meningkat merupakan metode standar ASTM D 1434 (Brown,1992). Sedangkan prinsip konsentrasi meningkat kondisi mantap (steady state) merupakan standar ASTM D 3985 (Brown, 1992) Metode ini semula hanya diterapkan untuk gas oksigen karena terbatasnya teknik pendeteksian gas, peralatan yang digunakan dalam metode ini trediri dari sel permeabilitas dengan dua ruangan yang dipisahkan oleh sample film plastic yang akan diuji. Salah satu ruangan dialiri dengan gas oksigen murni, sedangkan ruangan lainnya dialiri dengan campuran gas 98 $\%$ nitrogen dan $2 \%$ hidrogen. Konsentrasi gas oksigen yang terpermeasi ke dalam aliran gas nitrogen diukur menggunakan sensor oksigen setelah kondisi mantap (steady) tercapai.
Pengujian dengan menggunakan metode tekanan meningkat, volume meningkat dan konsentrasi meningkat kondisi tak mantap (unsteady) telah dilaporkan oleh Taylor and Proctor (1960). Metode tersebut direkomendasikan untuk pengujian permeabilitas gas pada film plastic alam. Pada mulanya dalam metode konsentrasi meningkat kondisi tak mantap, pengukuran konsentrasi gas dilalukan dengan menggunakan peralatan Orsat. Karel etal. (1963) memperkenalkan penggunaan kromatografi gas untuk pengukuran konsentrasi gas sehingga metode ini dapat dikembangkan untuk menentukan permeabilitasi gas-gas lain termasuk uap organic serta memungkinkan dilakukan pengulangan sampling.

Gilbert and Pegaz (1969) memperkenalkan sel untuk pengujian permeabilitas dengan tiga ruangan yang menggunakan dua lembar sample film plastic yang sama. Mannapperuma and Singh (1990) telah mengembangkan alat seperti yang digunakan Gilbert and Pegaz (1969) untuk pengukuran permeabilitas gas metode konsentrasi meningkat kondisi mantap (steady state). Prinsip dari metode ini ialah apabila dua ruangan dipisahkan oleh film yang masingmasing ruangan dialiri dengan gas murni yang berbeda untuk jangka waktu yang cukup lama sampai tercapai kondisi mantap (steady state), maka tiap ruangan tersebut akan berisi rembesan dari gas yang lain. Besarnya fraksi rembesan gas ini tergantung pada laju rembesan dari komponen gas dan laju alirannya. Prinsip ini dapat diimplementasikan untuk menentukan permeabilitas film plastic terhadap gas $\mathrm{CO}, 0$, dan N, secara simultan.

\section{BAHAN DAN METODE}

Bahan yang digunakan dalam penelitian ini adalah fim plastik, gas helium, oksigen, karbondioksida, nitrogen dan udara tekan. Sedangkan alat yang digunakan adalah tabung gas, regulator, klep buka tutup, klep jarum, soap bubble flow meter, sel permeabilitas, kromatografi gas HP 5890, "ten port valve", dan komputer dekstop. 


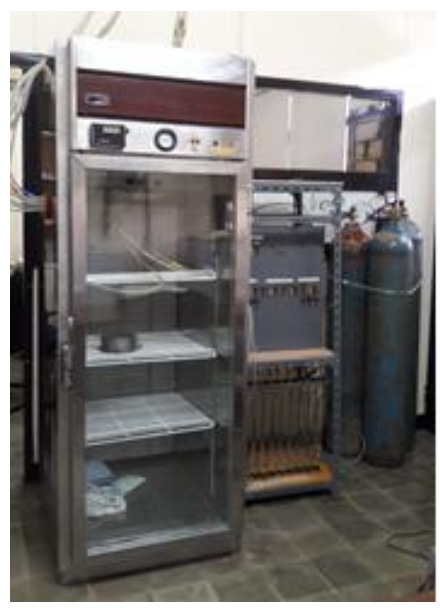

Gambar 1. Instrumen ukur permeabilitas gas

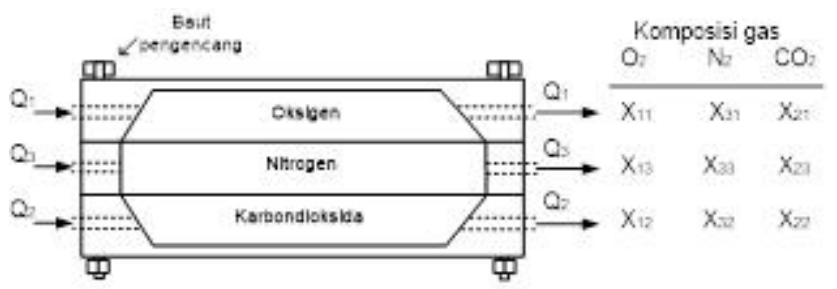

Gambar 2. Skema sel uji permeabilitas gas
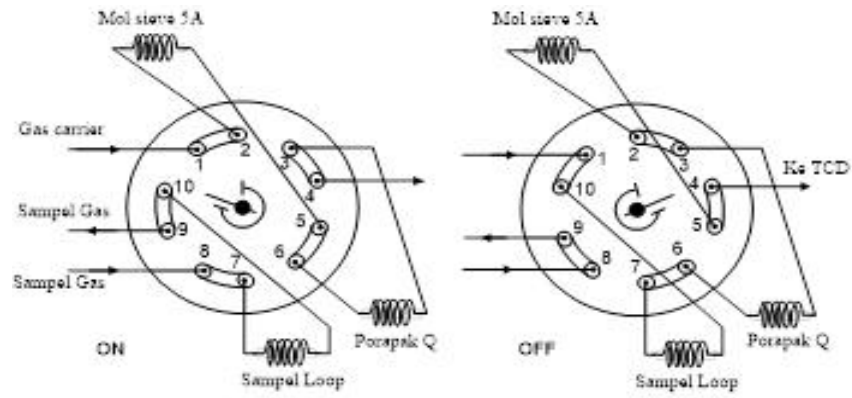

Gambar 3. Sampling gas secara otomatis menggunakan "ten port valve" untuk menganalisis gas $\mathrm{O}_{2}, \mathrm{CO}_{2}$ dan $\mathrm{N}_{2}$ secara simultan.

Pengukuran permeabilitas film plastik terhadap gas $\mathrm{CO}, \mathrm{O}$, dan $\mathrm{N}$, secara simultan dilakukan dengan menerapkan metode konsentrasi meningkat kondisi mantap (steady state concentration increase method) menggunakan sel permeabilitas dengan tiga ruang seperti yang telah dikembangkan oleh Mannapperuma dan Singh (1990). Analisis gas dilakukan menggunakan GC HP 5890 dengan detektor TCD (thermal conductivity detector). Instrumen engukuran permeabilitas gas diperlihatkan pada Gambar 1.

Untuk menghitung nilai permeabilitas digunakan persamaan kesetimbangan massa pada tiap gas yang terpermeasi dalam setiap aliran gas (Mannapperuma dan Singh 1990).
Notasi subskrip ganda digunakan untuk menyatakan konsentrasi gas dalam setiap aliran gas seperti diilustrasikan dalam Gambar 2 (Hasbullah, 2000). Subskrip pertama menyatakan gas terpermeasi, sedangkan subskrip kedua menyatakan gas pembawanya. Kesetimbangan massa untuk oksigen termeasi dalam aliran nitrogen dapat ditulis seperti pada persamaan (5). Terjadi kemungkinan untuk mendapatkan rembesan oksigen dalam aliran karbondioksida karena adanya permeasi sekunder. Hal ini dinyatakan dalam bagian kedua dari ruas kanan pada persamaan tersebut. Jika persamaan ini disusun kembali maka diperoleh persamaan (6) yang menyatakan nilai permeabilitas film plastic terhadap gas oksigen. 


$$
\begin{aligned}
& Q_{3} x_{13}=\frac{P_{1} A}{b\left(X_{11}-X_{13}\right)}+\frac{P_{1} A}{b\left(X_{12}-X_{13}\right)} \\
& P_{1}=\frac{Q_{3} b X_{13}}{A\left(X_{11}+X_{12}-2 X_{13}\right)}
\end{aligned}
$$

Kesetimbangan massa untuk karbondioksida terpermeasi dalam aliran nitrogen adalah seperti dinyatakan dalam persamaan (7) dengan menyusun kembali persamaan tersebut maka diperoleh persamaan (8) yang menyatakan nilai permeabilitas film plastik terhadap gas karbondioksida.

$$
\begin{aligned}
Q_{3} x_{23} & =\frac{P_{2} A}{b\left(X_{21}-X_{23}\right)}+\frac{P_{2} A}{b\left(X_{22}-X_{23}\right)} \\
P_{2} & =\frac{Q_{3} b X_{23}}{A\left(X_{21}+X_{22}-2 X_{23}\right)}
\end{aligned}
$$

Pengaruh suhu terhadap nilai permeabilitas gas dapat dinyatakan dalam bentuk persamaan Arrhenius seperti pada persamaan (9). Dengan mengetahui model persamaan Arrhenius maka dapat diduga nilai permeabilitas pada suhu tertentu. Dimana $\mathrm{P}=$ koefisien permeabilitas gas $\left(\mathrm{ml} . \mathrm{mm} / \mathrm{m}^{2}\right.$.hari.atm $), \quad$ Po $=$ faktor preeksponensial $\left(\mathrm{ml} . \mathrm{mm} / \mathrm{m}^{2}\right.$.hari.atm), Ea = energi aktivasi $(\mathrm{kJ} / \mathrm{mol}), \mathrm{R}=$ konstanta gas $(8.314$ $\mathrm{J} / \mathrm{mol} . \mathrm{K})$, dan $\mathrm{T}=$ suhu $(\mathrm{K})$.

$$
P=P_{o} \operatorname{Exp}\left(-\frac{E_{s}}{R T}\right)
$$

Komposisi gas meliputi $\mathrm{O}_{2}, \mathrm{CO}_{2}$ dan $\mathrm{N}_{2}$ dianalisis secara simultan menggunakan kromatografi gas (Gas chromatograph, GC) HP5890 dengan detektor TCD (thermal conductivity detector). Kondisi operasi GC adalah suhu kolom $70^{\circ} \mathrm{C}$, suhu injeksi $90^{\circ} \mathrm{C}$, suhu ten port $80^{\circ} \mathrm{C}$, suhu detektor $150{ }^{\circ} \mathrm{C}$. Jenis kolom yang digunakan adalah packed column jenis molecular sieve $5 \mathrm{~A}$ dan porapak R yang dihubungkan dengan "ten port valve" yang memungkinkan pemisahan gas-gas $\mathrm{O}_{2}, \mathrm{CO}_{2}$ dan $\mathrm{N}_{2}$ secara simultan. Gambar 3 menunjukkan "ten port valve" untuk sampling gas secara otomatis. Posisi ten port valve adalah "ON" pada menit ke 0.02 dan "OFF' setelah 2.0 menit. Puncak sinya gas $\mathrm{CO}_{2}, \mathrm{O}_{2}$ dan $\mathrm{N}_{2}$ masingmasing terjadi pada "retention time" berturutturut 3 menit, 4 menit dan 5 menit. Sebelum digunakan untuk menganalisis gas-gas pada sampel plastik, terlebih dahulu dilakukan kalibasi dengan menggunakan gas $1 \% 02,1 \% \mathrm{CO}_{2}$ dan 1 $\% \mathrm{~N}_{2}$ dalam gas helium.

\section{HASIL DAN PEMBAHASAN}

Hasil analisis konsentrasi gas $\mathrm{O}_{2}, \mathrm{CO}_{2}$ dan $\mathrm{N}_{2}$ selama percobaan pengukuran permeabilitas film plastik jenis polietilen stretch dan polipropilen disajikan pada Tabel 1 dan 2 . Koefisien permeabilitas gas ditentukan menggunakan Persamaan (8) dan (10). Gambar 4 menunjukkan permeabilitas gas dari film plastik jenis polietilen stretch dan polipropilena pada beberapa suhu penyimpanan. Dari gambar tersebut nampak adanya pengaruh yang kuat dari suhu penyimpanan terhadap permeabilitas gas baik permeabilitas terhadap $\mathrm{O}_{2}$ maupun $\mathrm{CO}_{2}$.

\begin{tabular}{|c|c|c|c|c|}
\hline \multirow[t]{2}{*}{ Laju Aliran Gas } & \multirow{2}{*}{$\begin{array}{c}\text { Suhu } \\
\left({ }^{\circ} C\right)\end{array}$} & \multicolumn{3}{|c|}{ Konsentrasi Gas (\%) } \\
\hline & & $\mathbf{O}_{2}$ & $\mathrm{CO}_{2}$ & $\mathbf{N}_{2}$ \\
\hline & 5 & 99,610 & 0,364 & 0,026 \\
\hline Oksigen & 10 & 99,481 & 0,451 & 0,068 \\
\hline \multirow[t]{3}{*}{$15 \mathrm{ml} / \mathrm{menit}$} & 15 & 99,315 & 0,553 & 0,133 \\
\hline & 20 & 99,213 & 0,634 & 0,154 \\
\hline & 25 & 98,812 & 0,953 & 0,236 \\
\hline & 5 & 0,057 & 99,909 & 0,035 \\
\hline Karbon dioksida & 10 & 0,011 & 99,911 & 0,079 \\
\hline \multirow{4}{*}{$15 \mathrm{ml} / \mathrm{jam}$} & 15 & 0,019 & 99,850 & 0,132 \\
\hline & 20 & 0,034 & 99,815 & 0,152 \\
\hline & 25 & 0,040 & 99,700 & 0,261 \\
\hline & 5 & 0,051 & 0,230 & 99,719 \\
\hline Nitrogen & 10 & 0,121 & 0,498 & 99,382 \\
\hline \multirow[t]{3}{*}{$10 \mathrm{ml} / \mathrm{jam}$} & 15 & 0,230 & 0,907 & 98,864 \\
\hline & 20 & 0,358 & 1,451 & 98,191 \\
\hline & 25 & 0,561 & 2,428 & 97,012 \\
\hline
\end{tabular}
Semakin tinggi suhu penyimpanan semakin tinggi nilai permeabilitas gas pada film plastik.

Tabel 1. Konsentrasi gas setelah kondisi "steady state" selama pengukuran permeabilitas gas pada film stretch 
Tabel 2. Konsentrasi gas setelah kondisi "steady state" selama pengukuran permeabilitas gas pada film polipropilen

\begin{tabular}{|c|c|c|c|c|}
\hline \multirow[t]{2}{*}{ Laju Aliran Gas } & \multirow{2}{*}{$\begin{array}{c}\text { Suhu } \\
\left({ }^{\circ} \mathrm{C}\right)\end{array}$} & \multicolumn{3}{|c|}{ Konsentrasi Gas (\%) } \\
\hline & & $\mathbf{O}_{2}$ & $\mathrm{CO}_{2}$ & $\mathrm{~N}_{2}$ \\
\hline & 5 & 99,552 & 0,433 & 0,016 \\
\hline Oksigen & 10 & 99,437 & 0,530 & 0,034 \\
\hline \multirow{3}{*}{$15 \mathrm{ml} / \mathrm{m}$ enit } & 15 & 99,333 & 0,615 & 0,053 \\
\hline & 20 & 99,172 & 0,715 & 0,114 \\
\hline & 25 & 99,032 & 0,833 & 0,136 \\
\hline & 5 & 0,008 & 99,982 & 0,011 \\
\hline Karbon dioksida & 10 & 0,028 & 99,949 & 0,024 \\
\hline \multirow{4}{*}{$15 \mathrm{ml} / \mathrm{m}$ enit } & 15 & 0,035 & 99,917 & 0,048 \\
\hline & 20 & 0,038 & 99,895 & 0,068 \\
\hline & 25 & 0,042 & 99,840 & 0,118 \\
\hline & 5 & 0,037 & 0,082 & 99,882 \\
\hline Nitrogen & 10 & 0,058 & 0,138 & 99,804 \\
\hline \multirow[t]{3}{*}{$10 \mathrm{ml} / \mathrm{menit}$} & 15 & 0,110 & 0,259 & 99,632 \\
\hline & 20 & 0,185 & 0,403 & 99,413 \\
\hline & 25 & 0,266 & 0,568 & 99,167 \\
\hline
\end{tabular}

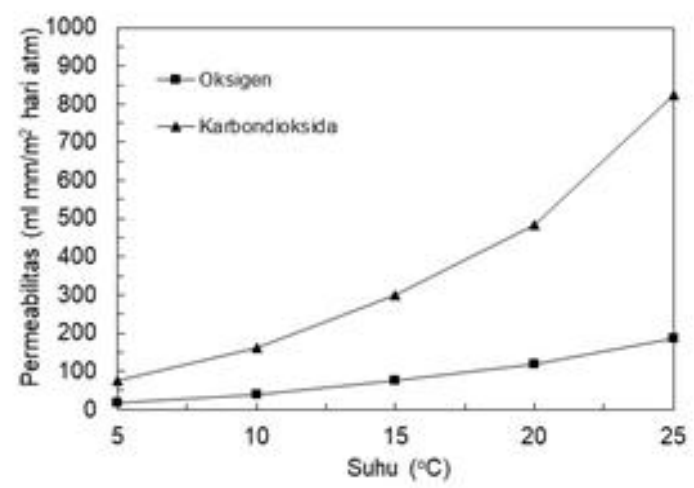

Gambar 4. Permeabilitas gas plastik polietilen stretch pada berbagai suhu penyimpanan

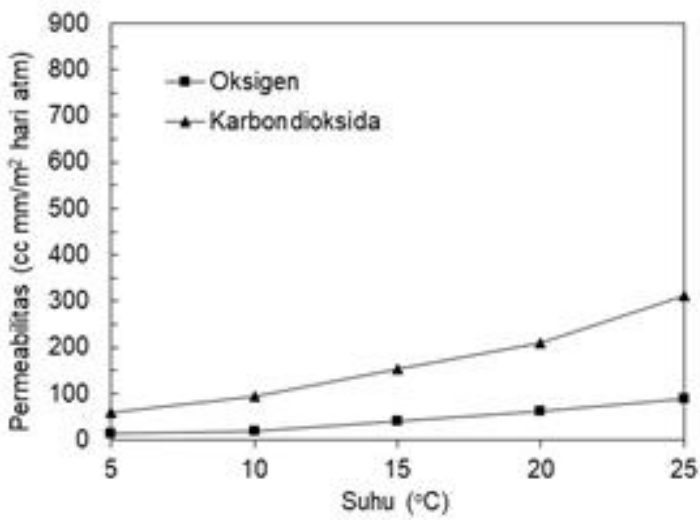

Gambar 5. Permeabilitas gas plastik polipropilen pada berbagai suhu penyimpanan

Pengaruh suhu terhadap permeabilitas gas film plastik jenis polietilen stretch dan polipropilen disajikan pada Gambar 4 dan 5. Permeabilitas gas meningkat dengan meningkatnya suhu dengan bentuk hubungan eksponensial.

Tabel 3 menunjukkan nilai permeabilitas gas pada berbagai suhu dan nilai rasio permeabilitas (b) pada film plastik jenis polietilen stretch dan polietilen yang digunakan pada percobaan ini. Rasio permeabilitas merupakan perbandingan antara permeabilitas gas $\mathrm{CO}_{2}$ terhadap permeabilitas gas $\mathrm{O}_{2}$. Nilai rasio permeabilitas adalah salah satu parameter penting dalam perancangan pengemasan secara atmosfir termodifikasi (MAP) untuk produk segar. 
Parameter penting lainnya dalam merancang pengemasan MAP adalah komposisi gas $\left(\mathrm{O}_{2}\right.$ dan $\mathrm{CO}_{2}$ ) yang optimum dan laju respirasi dari komoditas yang yang akan dikemas (Mannapperuma dan Singh, 1990). Paramaterparameter ini menentukan komposisi gas $\mathrm{O}_{2}$ dan $\mathrm{CO}_{2}$ di dalam kemasan yang targetnya adalah menekati komposisi gas yang optimum sehingga masa simpan produk dapat ditingkatkan (Zagory, 1992). Film dengan nilai rasio tinggi akan memungkinkan $\mathrm{CO}_{2}$ relatif lebih mudah lolos dari kemasan sehingga tidak terjadi akumulasi gas $\mathrm{CO}_{2}$ di dalam kemasan. Di sisi lain, film dengan nilai rasio yang lebih rendah akan memungkinkan penumpukan $\mathrm{CO}_{2}$ yang lebih besar didalam kemasan yang akan mempengaruhi mutu produk yang dikemas.
Rasio permeabilitas film plastik jenis polietilen stretch dan polipropilen dalam percobaan ini pada suhu $5-25{ }^{\circ} \mathrm{C}$ bervariasi antara 4.0 sampai 4.5 untuk film plastik jenis polietilen stretch dan antara 2.1 sampai 2.4. Untuk polipropilen, rasio permeabilitas yang diperoleh lebih rendah dari nilai rasio permeabilitas untuk film plastik jenis polietilen stretch. Hasbullah et al. (2000) melaporkan nilai rasio permeabilitas sebesar 2 untuk film plastik polipropilen dan 4.0 untuk film plastik polietilen stretch pada suhu $25{ }^{\circ} \mathrm{C}$. Berbagai faktor mempengaruhi pengukuran permeabilitas gas adalah kondisi pengujian, karakteristik film plastik dan metode uji. Untuk polietilen stretch, permeabilitas rasio mendekati nilai film polietilen densitas rendah (LDPE) yang dilaporkan oleh Mannapperuma dan Singh (1989) menggunakan metode yang sama.

Tabel 3. Nilai permeabilitas gas dan rasio permeabilitas $(\beta)$ pada film plastik jenis polietilen stretch dan polipropilen

\begin{tabular}{|c|c|c|c|c|c|c|}
\hline \multirow{3}{*}{$\begin{array}{c}\text { Suhu } \\
\left({ }^{\circ} \mathrm{C}\right)\end{array}$} & \multicolumn{4}{|c|}{ Permeabilitas gas $\left(\mathrm{ml} . \mathrm{m} \mathrm{m} / \mathrm{m}^{2}\right.$.hari.atm) } & \multicolumn{2}{|c|}{ Nilai $\beta$} \\
\hline & \multicolumn{2}{|c|}{ Pes } & \multicolumn{2}{|c|}{ PP } & \multirow{2}{*}{$\begin{array}{c}\text { PES } \\
\mathrm{O}_{2}\end{array}$} & \multirow{2}{*}{$\frac{\mathrm{PP}}{\mathrm{CO2}}$} \\
\hline & $\mathbf{O}_{2}$ & $\mathrm{CO}_{2}$ & $\mathbf{O}_{2}$ & $\mathrm{CO}_{2}$ & & \\
\hline 5 & 16,7 & 75,1 & 12,0 & 26,6 & 4,5 & 2,2 \\
\hline 10 & 39,6 & 163,1 & 19,0 & 44,9 & 4,1 & 2,4 \\
\hline 15 & 75,8 & 299,6 & 36,1 & 84,2 & 4,0 & 2,3 \\
\hline 20 & 118,4 & 484,6 & 60,8 & 131,6 & 4,1 & 2,2 \\
\hline 25 & 187,0 & 825,6 & 88,6 & 185,7 & 4,4 & 2,1 \\
\hline
\end{tabular}

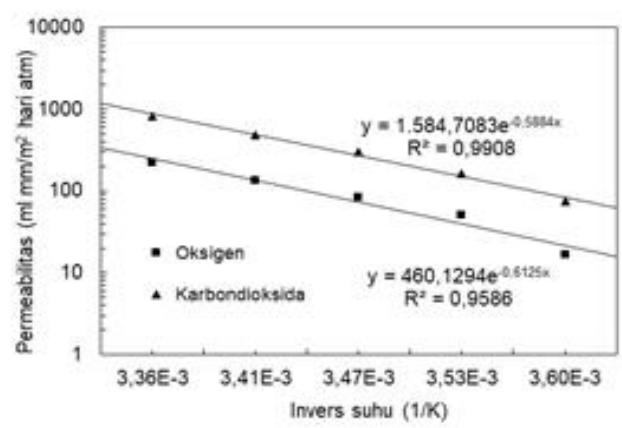

Gambar 6. Plot Arrhenius dari permeabilitas gas terhadap invers suhu pada plastik polietilen stretch

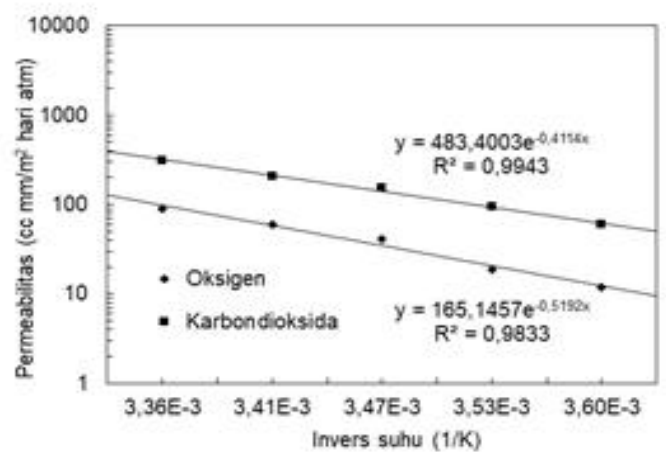

Gambar 7. Plot Arrhenius dari permeabilitas gas terhadap invers suhu pada plastik dan polipropilen 
Table 4. Nilai pra-exponensial dan energi aktivasi pada persamaan Arrhenius untuk plastik jenis polietilen stretch dan polippropilen

\begin{tabular}{ccccc}
\hline Jenis plastik & Gas & $\begin{array}{c}\text { Pra eksp. (ml.mm/m². } \\
\text { hari.atm) }\end{array}$ & $\begin{array}{c}\text { Energi Akktifasi } \\
\text { (J/mol) }\end{array}$ & $\mathbf{R}^{\mathbf{2}}$ \\
\hline Polietilen & $\mathrm{O}_{2}$ & 460,13 & 5,09 & 0,9586 \\
stretch & $\mathrm{CO}_{2}$ & 1584,71 & 4,89 & 0,9908 \\
\hline Polipropilen & $\mathrm{O}_{2}$ & 165,15 & 4,32 & 0,9833 \\
& $\mathrm{CO}_{2}$ & 483,40 & 3,42 & 0,9943 \\
\hline
\end{tabular}

Permeabilitas gas disajikan dalam bentuk plot Arrhenius pada Gambar 6 dan 7. Parameterparameter persamaan Arrhenius seperti konstanta pra eksponensial (Po) dan energi aktivasi (Ea) ditunjukkan pada Tabel 4. Korelasi permeabilitas gas untuk $\mathrm{O}_{2}$ dan $\mathrm{CO}_{2}$ dengan suhu penyimpanan cukup baik yang ditunjukkan dengan tingginya nilai koefesien determinasi $\left(\mathrm{R}^{2}\right)$. Nilai $\mathrm{R}^{2}$ hubungan antara permeabilitas gas dengan suhu penyimpanan berkisar antara 0.9586 dan 0.9943. Hasil ini menunjukkan bahwa persamaan Arrhenius dapat digunakan dengan tepat untuk menggambarkan pengaruhu suhu terhadap permeabilitas gas pada film plastik.

\section{KESIMPULAN}

Berdasarkan penelitian ini dapat disimpulkan bahwa:

1. Permeabilitas gas dari film plastik jenis polietilen stretch dan polipropilen meningkat dengan meningkatnya suhu penyimpanan secara eksponensial.

2. Model Arrhenius cukup baik untuk menggambarkan pengaruh suhu terhadap permeabilitas gas pada film plastik dengan nilai koefisien determinasi $\left(\mathrm{R}^{2}\right)$ berkisar antara 0.9586 dan 0.9943 .

3. Rasio permeabilitas gas $\mathrm{CO}_{2}$ terhadap gas $\mathrm{O}_{2}$ pada suhu $5-25^{\circ} \mathrm{C}$ berkisar antara 4.0 sampai 4.5 untuk film plastik polietilen stretch dan antara 2.1 sampai 2.4 untuk film plastik polipropilen.

\section{UCAPAN TERIMA KASIH}

Penelitian ini didanai dari Program Penelitian Terapan Unggulan Perguruan Tinggi (PTUPT) Tahun Anggaran 2018 Nomor: 1695/IT3.11/ PN/2018 Lembaga Penelitian dan Pengabdian kepada Masyarakat (LPPM), Institut Pertanian
Bogor. Untuk itu penulis mengucapkan terima kasih kepada Kementerian Ristek-Dikti dan LPPM IPB yang telah memberikan kesempatan kepada penulis untuk melakukan penelitian ini.

\section{DAFTAR PUSTAKA}

Brown (1992). Plastics in food packaging: properties, design, and fabrication. Marcel Dekker, Inc.New York.

Gilbert, S. G. and Pegaz, D.(1969). Find new ways to measure gas permeability, Package Engineering, 14(1): 66-69.

Hasbullah, R, Gardjito, A. M. Syarief and T. Akinaga. (2000). Gas permeability characteristics of plastic films for packaging of fresh produce. J. Society of Agricultural Structures, Japan, 31: 79-86.

Kader AA, Morris LL. (1977). Relative Tolerance of Fruits and Vegetables to Elevated CO2 and Reduce 02 Levels. Michigan (US): Michigan State University Hort Report 2.

Karel, M, Issenberg, P., Ronsivalli, L. and Jurin, V. (1963). Application of Gas chromatography to the measurement of gas permeability of Packaging materials. Food Technology.91:327

Mannapperuma, J. D, and Singh, R. P.(1990). Modeling of gas exchange in polymeric packages of fresh fruits and vegetables, Paper for ASAE Winter Meeting, Chicago, December 1990.

Mannapperuma, J. D., Zagory, D., Singh, R. P. And Kader, A. A.(1989). Design of polymeric packages for modified atmosphere storage of fresh produce. Presented at the Fifth International Controlled Atmosphere Research Conference, Wenatchee, WA, USA, June 14-16,1989.

Smock, R.M. (1979). Controlled Atmosphered of Fruits Horticultural Reviews Vol. 1. 
Westport (US): The AVIPublishing Co. Zagory, D.(1992). Extended shelf life packages Inc.

Taylor, A.A.M. and Proctor, B.E. (1960). Measurement of 0 , permeability. Modern Packaging. 33(10):131 for produce: new technology, new opportunities. Presented at the 9th Annual Foodplas Conference; Plastics Institute of America, Orlando, FL, March 3-5, 1992. 